\title{
TINJAUAN PRAKTIS MEMBENTUK PERILAKU SEHAT DAN HIDUP AKTIF PADA ANAK USIA DINI
}

Oleh: Suharjana

Dosen Jurusan Pendidikan Kesehatan dan Rekreasi FIK-UNY

\begin{abstract}
Abstrak
Orang yang kurang aktif bergerak dalam jangka panjang dapat menyebabkan tubuh tidak bugar dan muncul berbagai masalah kesehatan, terutama kegemukan dan penyakit kardiovaskular.

Agar manusia dapat hidup sehat dan diberi umur panjang, upaya yang harus ditempuh adalah dengan menjalankan pola hidup sehat, yaitu dengan berperilaku sehat dan aktif bergerak. Perilaku hidup sehat dan aktif bergerak hendaknya dimulai sejak usia dini.

Membiasakan anak hidup sehat dan aktif bergerak diperlukan kesungguhan guru dalam merancang kegiatan untuk anak. Disisi lain orang tua juga harus faham dan mampu menyediakan kebutuhan makan dan kesempatan gerak bagi anaknya. Guru bisa memberikan informasi-informasi untuk kepentingan pertumbuhan dan perkembangan anak didik. Orang tua juga dapat memberikan informasi penting tentang perkembangan anak dalam keluarga.
\end{abstract}

Kata kunci: pola hidup sehat, usia dini

Pada saat ini dunia telah masuk pada zaman yang sangat maju. Kemajuan teknologi telah membuat manusia di dunia terasa hidup berdekatan, hampir tidak ada batas baik ruang maupun waktu. Disisi lain perkembangan ilmu pengetahuan dan teknologi akan membuat manusia mudah dan cepat dalam melakukan kegiatan sehari-hari. Dampak negatif dari kemajuan teknologi ini atara lain dapat membuat manusia menjadi malas bergerak. Orang yang kurang aktif bergerak, dalam jangka panjang dapat menyebabkan tubuh tidak bugar dan muncul berbagai masalah kesehatan, terutama kegemukan dan penyakit kardiovaskular. Di negara maju seperti Amerika Serikat, kecenderungan terjadinya kasus stroke semakin meningkat. Faktor utama penyebabnya adalah kegemukan dan konsumsi makanan dengan mutu rendah (junk food). Berdasarkan data statistik di Amerika Serikat, setiap tahun terjadi 750.000 kasus stroke (http://exuico.multiply.com).

Perilaku hidup sehat dan aktif bergerak hendaknya dimulai sejak usia dini. Seperti dinyatakan dalam Undang-undang Nomor 20 Tahun 2003, tentang Sistem Pendidikan Nasional, bahwa Pendidikan Anak Usia Dini (PAUD) adalah suatu upaya pembinaan yang ditujukan bagi anak-anak sejak lahir sampai dengan usia enam tahun yang dilakukan melalui pemberian rangsangan pendidikan untuk membantu pertumbuhan dan perkembangan jasmni dan rohani agar anak memiliki kesiapan dalam memasuki pendidikan lebih lanjut. Sharkey (2003: 30) menyatakan bahwa untuk mencapai "quality of life" aspek-aspek yang harus 


\section{MEDIKORA Vol. VIII, No 2 April 2012}

dipenuhi, antara lain adalah: (1) mengatur makanan, (2) menjaga kesehatan pribadi, (3) mengatur istirahat, dan (4) aktif bergerak.

\section{PEMBAHASAN}

\section{Pengaturan Makan bagi Anak}

Mengatur makanan prinsipnya adalah bagaimana tubuh dapat mengkonsumsi makanan sehari-hari yang mengandung zat-zat gizi yang seimbang. Di Indonesia sebagai penuntun prilaku konsumsi makanan sehat di masyarakat, digunakan Pedoman Umum Gizi Seimbang (PUGS), yaitu 60-70\% kebutuhan energi diperoleh dari karbohidrat, 1015\% dari protein, dan 10-25\% dari lemak (Sunita Almatsier: 2005: 13). Agar makanan yang dikonsumsi sesuai kebutuhan tubuh, makanan tersebut harus ditakar. Cara yang mudah untuk menentukan takaran makan, adalah berhenti makan sebelum kenyang atau disebut Low Calory Eating atau 70\% - 80\% kenyang setiap kali makan. Di Indonesia makanan dengan zat-zat gizi seimbang dikenal dengan motto "Empat Sehat Lima Sempurna" yang terdiri atas makanan pokok, lauk pauk, sayur-mayur, buah-buahan, dan susu.

Bagi anak-anak penyediaan makanan tidak berbeda dengan penyediaan makanan bagi orang dewasa. Akan tetapi yang perlu diperhatikan adalah zat gizi yang terkait dengan proses pertumbuhan, yakni protein. Karena kekurangan protein dapat menyebabkan terhambatnya pertumbuhan tubuh, terutama tinggi badan. Anak-anak yang berusia antara 1 sampai dengan 3 tahun belum dapat menyebutkan nama-nama makanan yang diinginkan, sehingga makanan untuk anak usia ini dipilihkan oleh orang tuanya. Sedangkan anak pada usia di atas 3 tahun (4-5 tahun) sudah mulai bisa menyebut dan minta makanan dan mereka sudah dapat memilih makanan yang disukai. Banyak ditemui orang tua geram, karena anaknya tidak mau makan. Menurut Kus Irianto (2004: 71) anak yang tidak mau makan menunjukkan sikap sebagai berikut: 1) menunjukkan sikap enggan saat waktunya makan, 2) enggan membuka mulut, 3) makan tidak dikunyah tapi hanya diemut, 4) menolak jika disuruh makan, 5) jika ingin makan hanya relatif sedikit, 6) menyukai jenis makanan tertentu, dan 7) lebih suka ngemil (coklat, permen, dan biskuit).

Orang tua memiliki peran penting dalam menyediakan makanan bergizi bagi anaknya. Pertumbuhan tinggi badan biasanya sering digunakan sebagai pertanda kecukupan gizi anak. Karena itu pemberian protein pada anak akan berpengaruh terhadap pertumbuhan anak, jika protein tidak tercukupi maka pertumbuhannya akan terhambat. Membimbing anak menyukai makanan lengkap 4 sehat 5 sempurna. Anak usia dini 


\section{MEDIKORA Vol. VIII, No 2 April 2012}

memerlukan makanan yang cukup, karena anak-anak dalam masa pertumbuhan fisik dan mental yang sangat cepat. Menurut Kus Irianto (2004: 72) kebutuhan energi dan protein tiap hari pada anak-anak seperti tabel berikut ini:

Tabel. Nilai Kebutuhan Energi pada Anak-Anak Kus Irianto (2004: 72)

\begin{tabular}{|c|c|c|c|}
\hline Usia & Berat badan/tinggi badan & Energi (kalori) & Zat Protein (gr) \\
\hline $1-3$ th & $12 \mathrm{~kg} / 89 \mathrm{~cm}$ & 1.220 & 23 \\
\hline $4-6 \mathrm{th}$ & $18 \mathrm{~kg} / 108 \mathrm{~cm}$ & 1.720 & 32 \\
\hline
\end{tabular}

Biasakan anak-anak makan pagi, karena kebanyakan anak-anak malas sarapan pada saat akan berangkat sekolah dengan berbagai alasan seperti tidak lapar, keburu terlambat, nanti beli di kantin sekolah. Kebiasaan anak yang tidak suka makan pagi dapat menyebabkan lambung kosong, dan cadangan tenaga berkurang sehingga anak akan menjadi lemas, ngantuk, tidak konsentrasi dan gairah belajar mnenjadi menurun. Menurut Djoko Pekik Irianto (2006: 164) permasalahan gizi yang sering dialami oleh anak-anak adalah:

a. KKP (Kekurangan Kalori Protein). KKP dikarenakan oleh rendahnya konsumsi protein hewani, hal ini biasanya dialami anak-anak dari keluarga kurang mampu yang tidak mampu menjangkau sumber makanan seperti daging, ikan atau telor

b. KVA (Kekurangan Vitamin A). Lazimnya anak-anak sekarang tidak suka mengkonsumsi sayuran maupun buah-buahan sebagai sumber vitamin A. Hal ini menyebabkan anak bisa kekurangan vitamin A (avitaminose A).

c. AGB (Anemia Gizi Besi). Zat besi banyak terdapat pada makanan hewani serta sayuran warna hijau tua. Anak-anak yang kurang meyukai makanan sayuran hijau akan dapat beresiko kekurangan zat besi (anemia)

d. GAKI (Gangguan Akibat kekuarangan Iodium). Munculnya permasalahan gizi ini lebih disebabkan kurangnya anak mengkonsumsi makanan yang beraneka ragam dan ketidakteraturan pola makan. Garam beryodium merupakan upaya untuk menghindarkan masyarakat dari kekurangan iodium.

Agar anak dapat tumbuh dan berkembang dengan baik maka kecukupan gizi harus dijaga. Oleh karena itu perlu pengaturan makanan yang baik. Makanan yang baik bagi anak-anak adalah: 1) makanan harus cukup kalori, 2) makanan harus mengandung lauk 


\section{MEDIKORA Vol. VIII, No 2 April 2012}

pauk (daging, ikan, telor, tempe, dan tahu), 3) makanan harus ada sayuran hijau, dan 4) konsumsi susu atau penggantinya seperti keju, atau es krim.

\section{Menjaga Kesehatan Pribadi}

Menurut Kus Irianto (2004: 83) menjaga kesehatan tubuh dilakukan dengan cara:

a. Mandi dua kali sehari.

b. Menggosok gigi. Menggosok gigi sebaiknya dilakukan setiap kali selesai makan.

c. Pakaian harus bersih.

d. Rambut harus bersih. Rambut harus tetap dirawat supaya tetap bersih. Kotoran di rambut bisa menimbulkan bau setelah 24 jam, karena itu membersihkan rambut sehari sekali akan lebih baik.

e. Kebersihan tangan dan kaki.

\section{Mengatur Istirahat}

Istirahat yang baik untuk orang dewasa adalah tidur selama 7-8 jam setiap hari. Anak yang baru lahir biasanya tidur selama 16-20 jam yang dibagi menjadi 4-5 periode. Menjelang usia 1 tahun biasanya anak hanya perlu tidur siang satu kali saja dengan total jumlah waktu tidur berkisar antara 12-14 jam. Mulai usia 2 tahun, anak tidur selama 12-13 jam, dengan 1-2 jam tidur siang dan 11 jam tidur malam. Sejak usia 6 tahun umumnya seorang anak memerlukan waktu tidur sebanyak 11 jam, tanpa tidur siang. Di usia 10 tahun biasanya anak tidur selama 10 jam (http://sleepclinicjakarta.tblog.com/post/1969889871).

\section{Aktif Bergerak}

Gaya hidup kurang aktif menyebabkan resiko kematian lebih besar jika dibandingkan dengan penyebab lainnya, karena kekuatangan aktivitas fisik dianggap sebagai faktor resiko utama untuk penyakit jantung, kolesterol tinggi dan tekanan darah tinggi. Untuk mencapai kesehatan dan kebugaran anak selain mengatur pola makan dan beristirahat teratur, anak harus dibiasakan aktif bergerak. Aktif bergerak berarti anak harus menggerakkan jasmani yang dilakukan secara rutin dalam setiap harinya ataupun aktivitas yang terprogram di sekolah. Aktif bergerak bagi anak dapat dilakukan di 


\section{MEDIKORA Vol. VIII, No 2 April 2012}

sekolah dan di rumah. Aktivitas gerak di sekolah terdiri atas pendidikan jasmani di sekolah dan aktivitas gerak lain selama di sekolah. Sedangkan aktivitas gerak di rumah mencakup kegiatan bermain atau aktivitas lainnya yang mengandung unsur kerja jasmani.

\section{a. Aktivitas gerak di rumah}

1) Biarkan anak bermain menurut kesukaannya. Anak laki-laki biasanya suka bersepeda atau bermain kejar-kejaran dengan teman-temannya. Anak-anak perempuan suka bermain lompat tali/lompat karet atau pasar-pasaran

2) Siapkan alat-alat yang dapat merangsang gerak bagi anak yang mudah dan aman untuk dimainkan dalam rumah, misalnya bola plastik, bola tenis, dan pistolpistolan.

\section{b. Aktivitas gerak di ruang kelas}

Aktivitas dalam ruangan kelas dapat dilakukan disela-sela pelajaran atau pun ditengah-tengah pelajaran sebagai selingan. Gunakan alat yang ada serta manfaatkan ruang-ruang yang kosong di antara peralatan yang ada dalam kelas. Adapun aktivitas yang dapat dilakukan menurut Hinson (1995) dan Anderson (1988) antara lain adalah sebagai berikut:

1) Jumping Jack (lompat tepuk) 


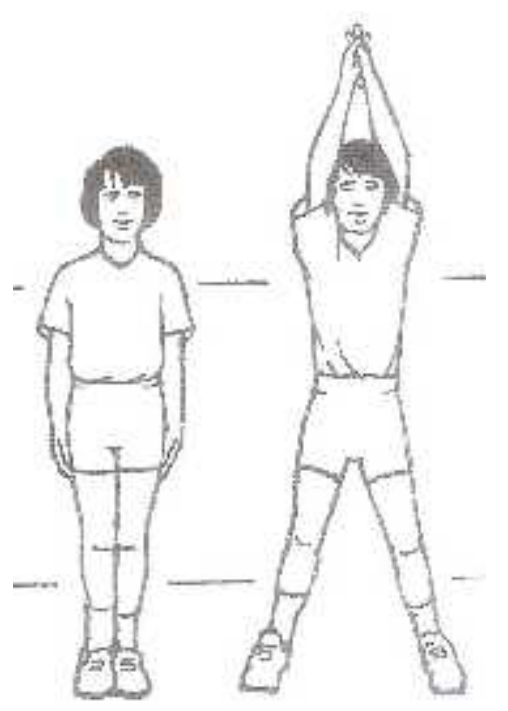

2) Wall Push-Ups (push-ups ke tembok)

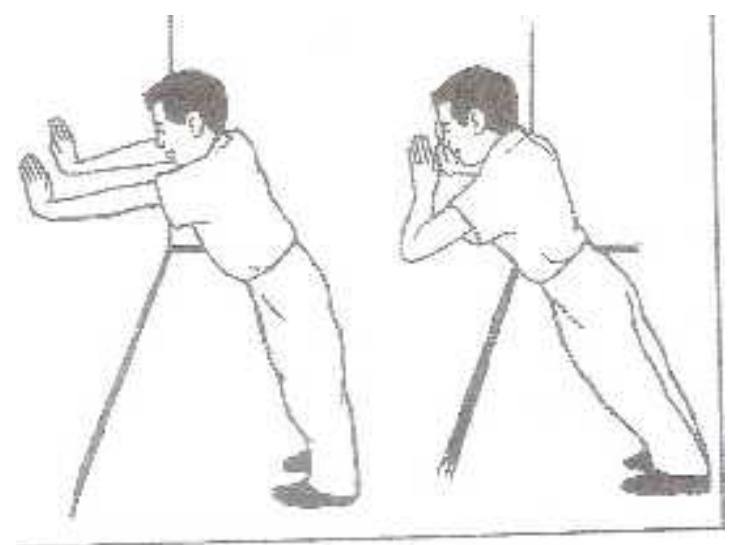

Anak disuruh berdiri berderet menghadap tembok dengan jarak yang cukup, lengan lurus tangan menapak di tembok. Guru memberi aba-aba. Gerakan dimulai dengan cara menekuk siku merebahkan badan ke tembok, kemudian lengan diluruskan kembali seperti semula. Lakukan gerakan ini diulangulang.

3) Stretching (Penguluran)

Lakukan penguluran di antara pelajaran satu dengan yang lain atau pada saat-saat pelajaran. Penguluran dapat dilakukan sambil duduk di kursi atau sambil berdiri. Berikut ini contoh bentuk-bentuk penguluran yang dapat dilakukan pada anak-anak 

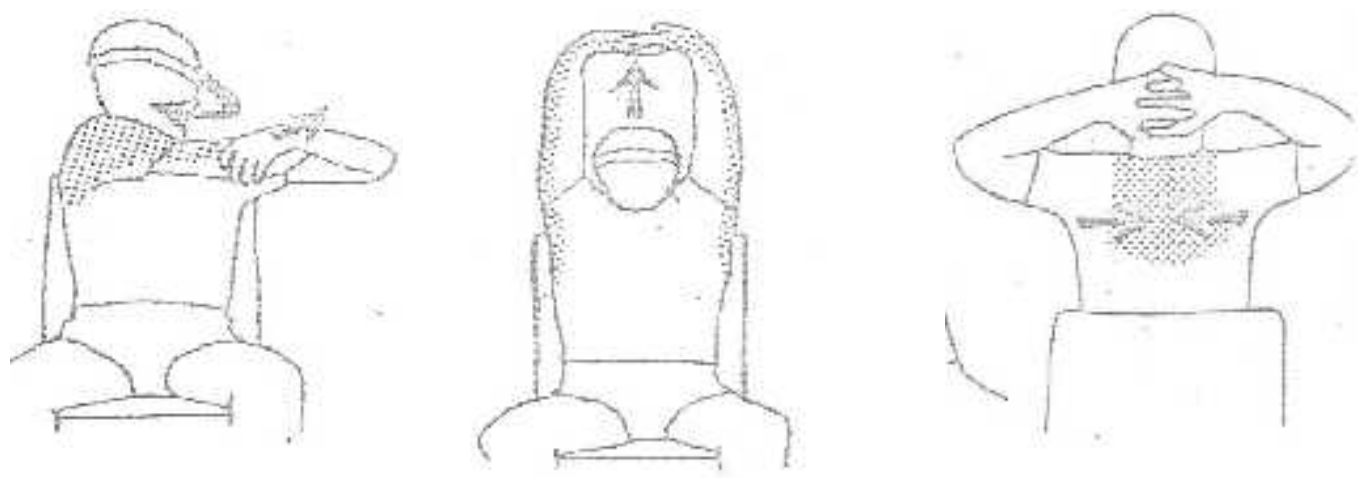

Lakukan penguluran Penguluran pada otot Penguluran pada otot pada lengan dan bahu, bergantian kanan dan kiri (10 kali hitungan).

lengan bagian depan $(10$ bagian punggung(10 kali kali hitungan).

hitungan).
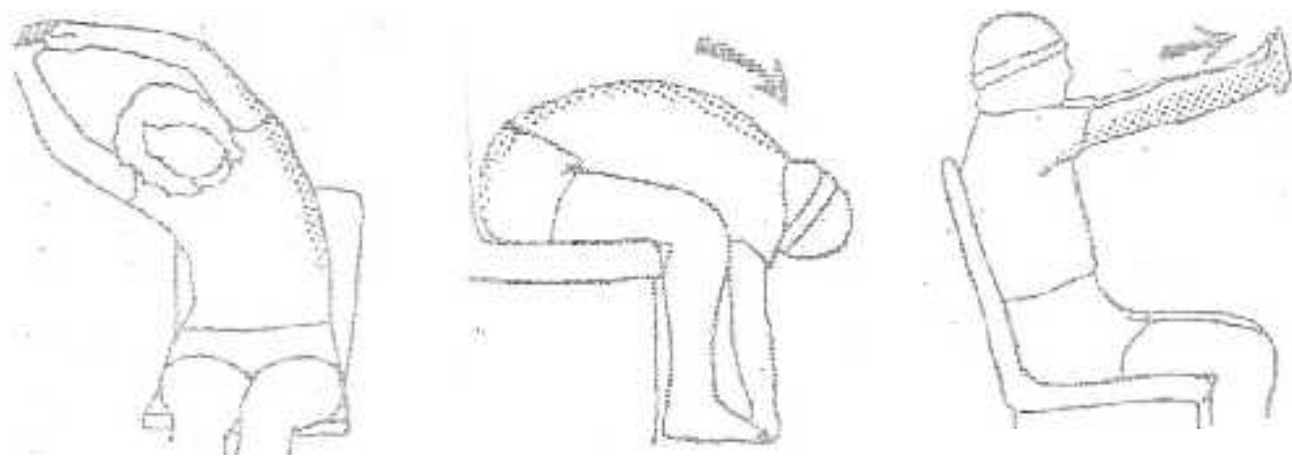

Penguluran untuk otot-

Penguluran untuk otot-

Penguluran untuk otototot tubuh bagian samping (10 kali otot bagian tubuh bagian otot lengan bagian belakang(10 kali samping (10 kali hitungan). hitungan). hitungan).

4) Berdiri satu kaki

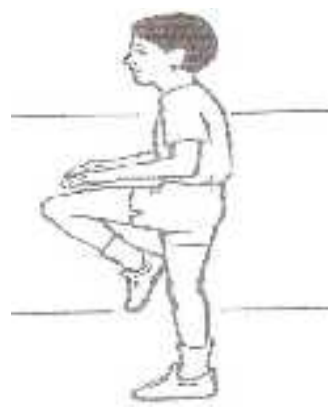

Anak-anak disuruh berdiri disamping meja, salah satu kakinya diangkat dan ditekuk. Berilah hitungan 5 sampai 10 kali. Cobalah dengan kaki yang lain. Gerakan ini dapat dilakukan disela-sela pelajaran. Sebagai variasi, kaki yang menumpu jinjit, lengan ke atas atau ke samping, mata dapat juga dipejamkan. 


\section{(5) Hopscotch}

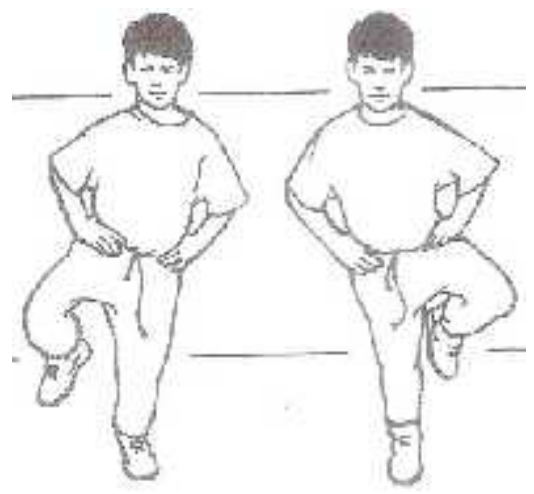

Anak-anak disuruh bediri satu kaki, kedua tangan di pinggang. Kemudian anak disuruh melompat ke atas atau dari tumpuan satu kaki, dan mendarat dengan satu kaki yang lain. Lakukan gerakan ini berkali-kali 6-8 kali dengan berganti-ganti kaki tumpu.

(6) Lari di tempat

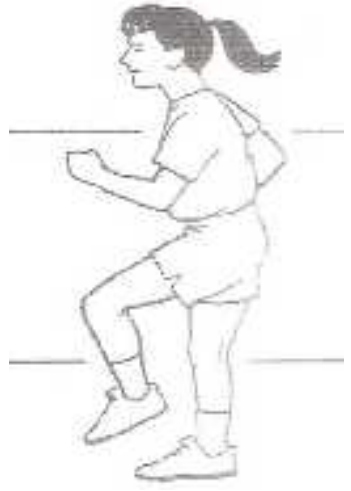

Anak-anak disuruh bediri, kemudian disuruh lari-lari ditempat. Sebagai variasi lari dapat dilakukan dengan irama lambat makin lama makin cepat atau sebaliknya. Lari di tempat juga dapat dilakukan dengan paha diangkat agak tinggi dengan irama pelan-pelan.

(7) Stride jump

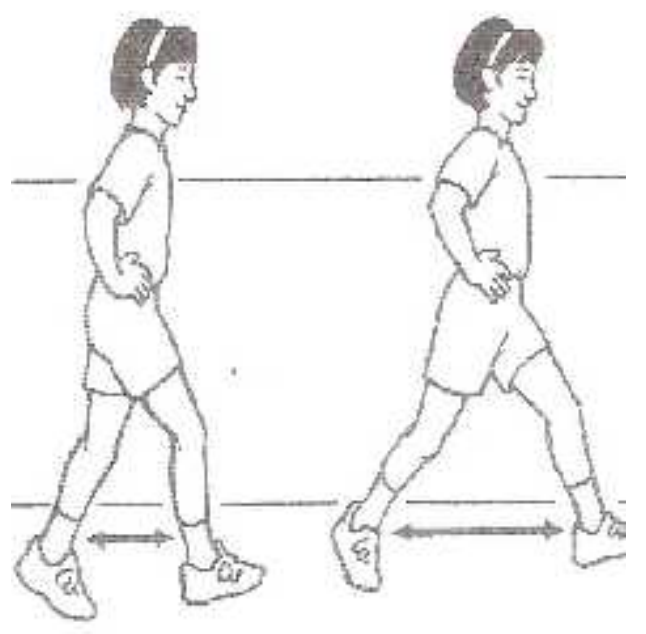

Anak-anak disuruh bediri dengan posisi kaki kiri di depan dan kaki kanan di belakang, kedua tangan di pinggang. Kemudian anak disuruh melompat sambil memindahkan kaki kiri ke belakang dan kakai kanan ke depan, sehingga ketika mendarat kaki kiri di belakang dan kaki kanan di depan. Lakukan gerakan ini 6-8 kali 


\section{c. Aktivitas di luar kelas}

1) Baris sebelum masuk kelas. Sebelum masuk kelas anak-anak disuruh berbaris berbanjar ke belakang, menjadi 2 atau 3 banjar. Kemudian disuruh masuk kelas satu persatu.

2) Untuk memberi kesempatan bermain, halaman sekolah sebaiknya dibuat arena bermain. Arena bermain yang dapat merangsang gerak pada saat anak istirahat. Gambar berikut ini contoh halaman sekolah yang di rancang dengan berbagai peralatan bermain anak-anak seperti alat untuk ayunan, telusuran, gelantungan. Diantara alat-alat tersebut juga disediakan fasilitas untuk jalan, berlari, melompat. Juga ada tempat untuk bermain bola dan permainan lainnya. Biasakan anak-anak untuk menggunakan alat-alat permainan ini. Untuk aktivitas jalan (walk), lari (run) lompat (skip), gallop (engklek) dan hop (loncat) juga dapat dilakukan setiap pagi sebelum masuk kelas (Hinson, 1995).

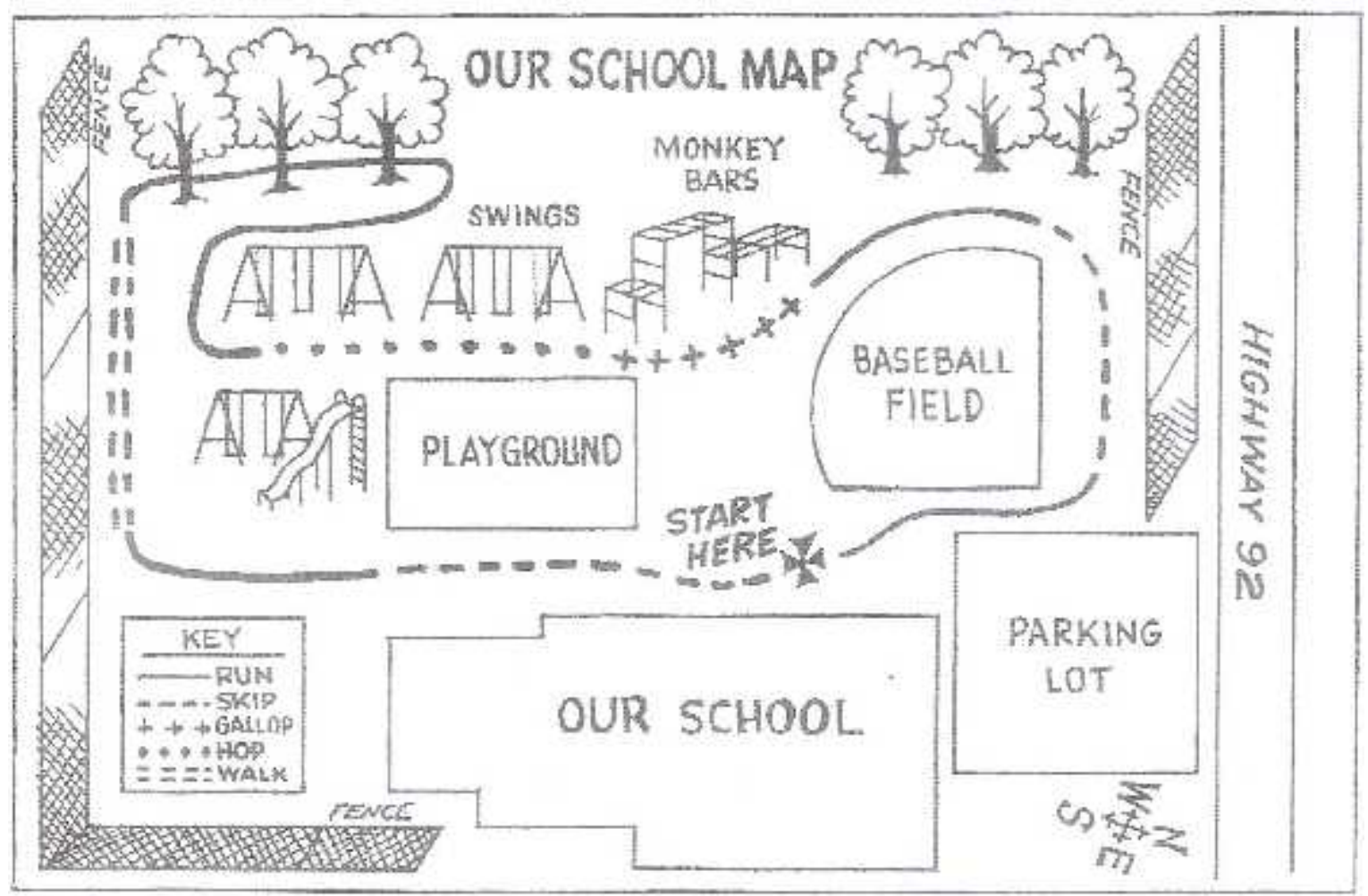

Gambar. Area bermain di lingkungan sekolahan (Hinson, 1995).

3) Jika punya halaman berlantai buatlah arena hopscotch (berjingkat) (Poppen,2002) 


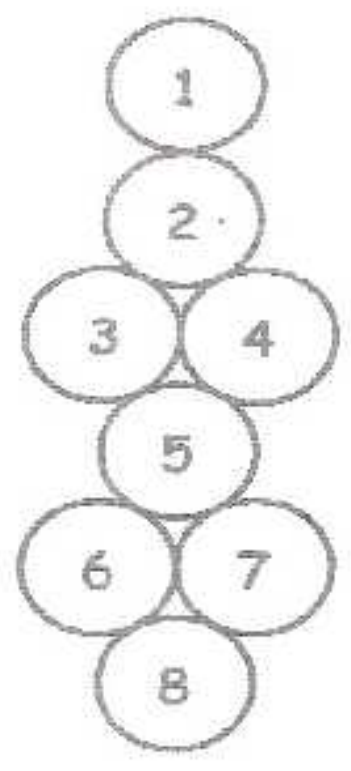

Anak berdiri dua kaki, kemudian disuruh melompat dan mendarat dengan kaki kanan pada angka satu, kemudian menolak dengan kakai kanan mendarat pada angka 2, kemudian menolak lagi mendarat dengan dua kaki, yakni kaki kanan diangka satu, kaki kiri dingaka 4, kemudian melompat lagi dan mendarat satu kaki pada angka 5, menolak dan mendarat dua kaki pada angka 6 dan 7

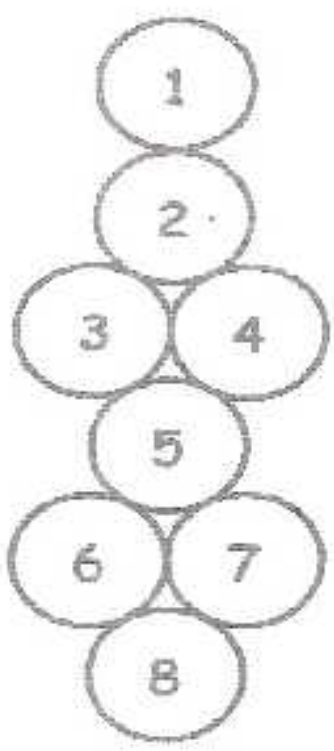
kemudian menolak dan mendarat dengan satu kaki kanan diangka 8

\section{d. Aktivitas jasmani terprogram di sekolah}

Hampir setiap hari anak-anak akan mendapatkan pelajaran pendidikan jasmani di sekolah. Pelajaran pendidikan jasmani untuk anak-anak harus dikemas dalam bentuk bermain. Berikut ini contoh-conoh aktivitas bermain untuk anak-anak yang bisa disampaikan pada pelajaran pendidikan jasmani (Mochamad Djumidar, 2004; Chu, 1992; Poppen, 2002) sebagai berikut:

(1) Melempar bola ekor

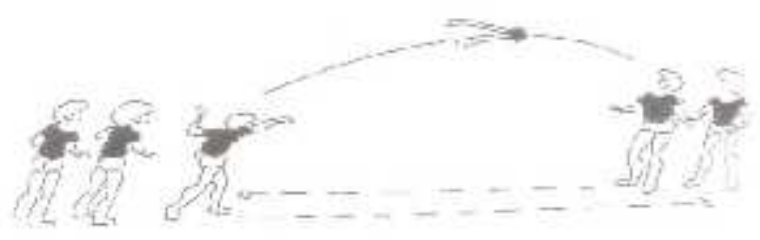

Anak disuruh melempar bola ekor (bola tenes) ke arah depan, teman yang lain berjaga untuk mengambil bola. Lemparan bola juga dapat dilempar ke arah atas. Bola juga dapat di lempar ke bawah sehingga bola memantul ke atas

(2) Melempar bola besar 


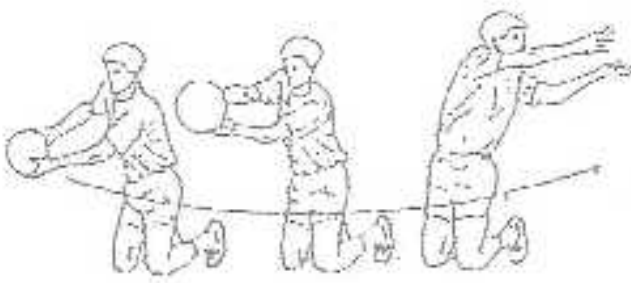

Anak disuruh melempar bola besar (bola plastik atau bola voli mini) dengan dua tangan kearah samping. Juga dapat dilempar dengan dua tangan kearah depan atau ke arah belakang. Bola bersa juga dapat digunakan melatih anak untuk menendang bola atau menggiring bola.

(3) Memberikan bola

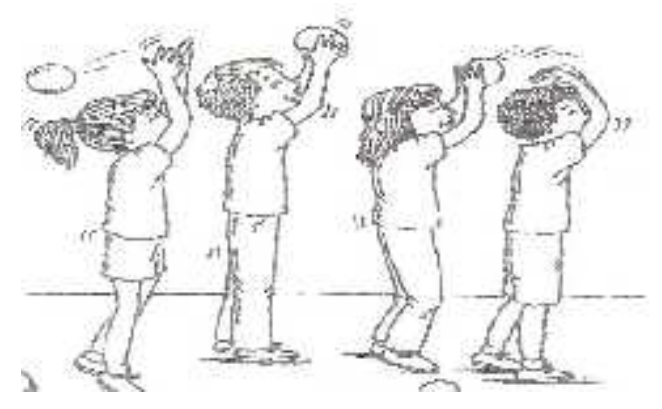

Anak disuruh berdiri berbanjar dibagi menjadi 2 atau 3 kelompok. Anak disuruh berlomba memberikan bola leabak paling belakang pemenangnya. Untuk variasi bola juga dapat diberikan lewat bawah di antara dua kaki. Juga dapat diberikan lewat samping.

(4) Berjalan kelompok memegang bahu

Anak-anak disuruh berdiri berbanjar menjadi 3-6

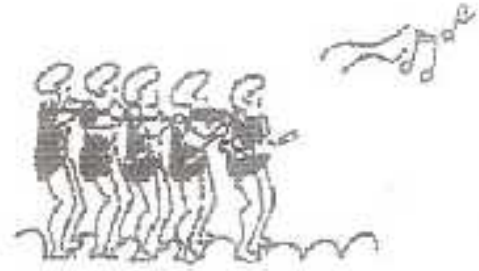
kelompok dengan posisi memegang bahu. Kemudian disuruh berjalan dari satu tempat ke tempat yang lain yang ditentukan oleh guru. Aktivitas ini juga dapat dilombakan dengan berjalan dari satu garis strat menuju garis finis. 
(5) Berjalan formasi bintang empat

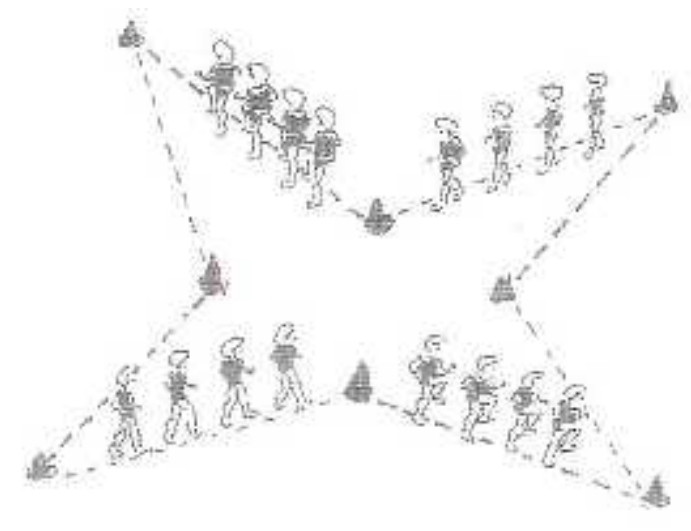

Guru membuat lapangan berbentuk bintang dengan 4 mata. Pada sudutsudut dibuat penanda (diberi con). Anak disuruh berjalan mengikuti garis bintang. Sebagai variasi dapat dilakukan dengan cara berlari pelan, engklek, lompat-lompat, atau berjalan mundur.

(6) Lompat tali/karet

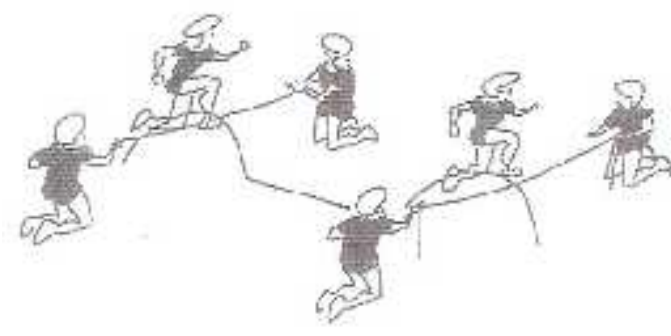

Guru menyiapkan tali karet dengan panjang 3-4 meter. Dua anak disuruh memegang tali pada masing-masing ujung karet dengan posisi berdiri pada lutut. Anak-anak yang lain disuruh melompati karet secara bergantian

(7) Melompati rintangan

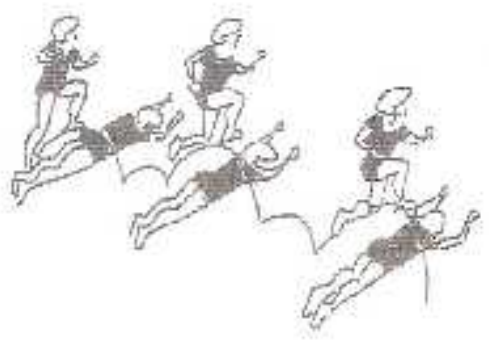

Buatlah formasi dengan 4-6 anak disusuh tengkurap kedua kaki lurus dan rapat, dengan jarak kurang lebih satu meter. Anak-anak yang lain disuruh melompati satu persatu. Untuk variasi dapat menggunakan kaki kanan dahulu kemudian diulang dengan kaki kiri. Jika mungkin juga dapat meloncat bertumpu dan mendarat dengan kedua kaki. Rintangan juga dapat diganti dengan kardus/kotak

(8) Memindah simpai 


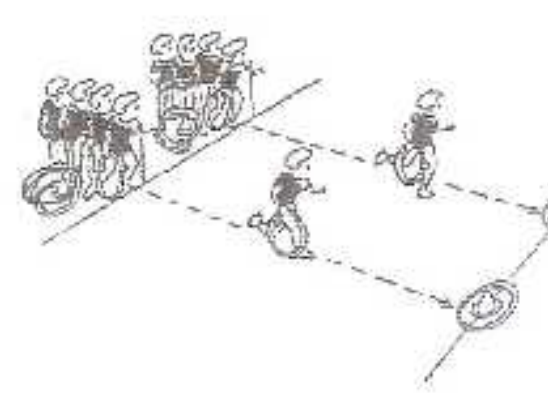

Anak-anak dibagi menjadi 2 aau 3 kelompok disuruh baris kebelakang. Anak satu persatu disuruh berlari memindahkan sampai dari tempat berbaris menuju ke pancang di depannya. Aktivitas ini juga dapat dilakukan dengan berpasangan dua anak- dua anak.

(9) Memindahkan kotak

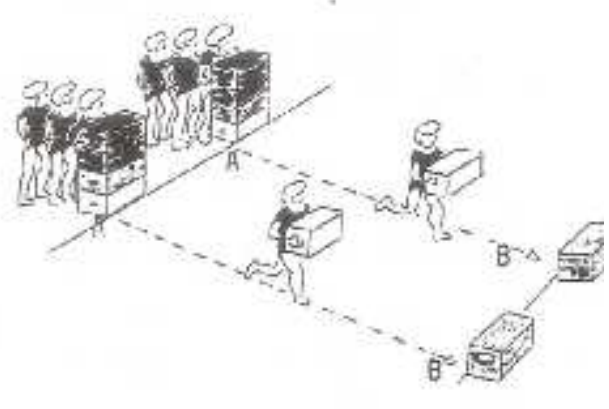

Anak-anak dibagi menjadi 2 aau 3 kelompok disuruh baris ke belakang. Anak satu persatu disuruh berlari memindahkan kotak dari tumpukan dekat tempat berbaris menuju ke garis di depannya dalam bentuk tumpukan juga. Aktivitas ini juga dapat dilombakan.

\section{KESIMPULAN}

Berdasarkan uraian pada pembahasan tersebut di atas dapat disimpulkan bahwa untuk membiasakan anak hidup sehat dan aktif diperlukan kesungguhan guru dalam merancang kegiatan untuk anak. Disisi lain orang tua juga harus paham dan dapat menyediakan kebutuhan akan dan kesempatan gerak bagi anaknya. Guru bisa memberikan informasi penting untuk kepentingan pertumbuhan dan perkembangan anak. Orang tua juga dapat memberikan informasi penting tentang perkembangan anak dalam keluarga.

Dapat dipahami bahwa untuk pertumbuhan dan perkembangan anak harus mengkonsumsi makanan yang cukup, yaitu menganut formula empat sehat lima sempurna yang terdiri nasi, lauk, sayur, buah, dan susu. Selain itu anak juga harus menjaga kebersihan badan dengan mandi dua kali sehari, menggosok gigi, mencuci kaki dan tangan jika kotor. Anak juga harus diperhatikan istirahatnya terutama anak perlu tidur yang cukup pada malam hari.

Untuk kebutuhan gerak anak harus difasilitasi dengan model-model gerak yang dikemas dalam bentuk bermain. Aktivitas dilakukan dengan rutin. Aktivitas dapat dilakukan di dalam kelas, di luar kelas, dalam bentuk pembelajaran penjas ataupun terintegrasi dengan pelajaran yang lain. Di rumah juga harus diberi fasilitas bermain yang cukup sesuai kesukaan anak. 


\section{MEDIKORA Vol. VIII, No 2 April 2012}

\section{DAFTAR PUSTAKA}

Anderson, Bob. (1988). Streching. Colorado: Shelter Publication.

Chu, Dhonald, A. (1992). Jumping Into Plyometrics. Illinois: Leisure Press.

Djoko Pekik Irianto. (2006). Panduan Gizi Lengap. Yogyakarta: Andi.

Hinson, C. (1995). Fitness for Children. Leeds. England: Human Kinetics. http://sleepclinicjakarta.tblog.com/post/1969889871. Pola Tidur Anak. Diunduh 10 April 2012

Kus Irianto. (2004). Gizi dan Pola Hidup Sehat. Bandung: CV. Yrama Widya.

Mochamad Djumidar A.W. (2004). Belajar Berlatih Gerak-Gerak Dasar Atletik dalam Bermain. Jakarta: PT. Rajagrafindo Persada.

Poppen, Jerry, D. (2002). 201 Ganes for Elementary Physical Education Program. USA: Parker Publishing Company.

Sunita Almatsier. (2005). Penuntun Diet. Jakarta: PT Gramedia Pustaka Utama. 